\title{
Da polarização da Escola Inglesa em torno das intervenções humanitárias à Responsibility to Protect: o lugar das instituições internacionais no middle ground teórico.
}

\author{
From the English School divide around the question of \\ humanitarian interventions to the Responsibility to Protect: \\ a place for international institutions within the middle ground.
}

Cláudia Alvarenga Marconi*

\section{Resumo}

0 presente artigo pretende, de modo geral, resgatar o debate pluralista-solidarista da Escola Inglesa (EI), que polariza a perspectiva teórica das RI assumidamente de middle ground e que é responsável por atualizá-la de meados dos anos 1990 em diante. A partir deste debate interno à Escola, focaremos em uma das questões internacionais que mais a desafiou no sentido de manter a virtude da via média: as intervenções de caráter humanitário dos anos 1990 em diante e seus desdobramentos sob a doutrina da Responsibility to Protect (R2P), formalmente institucionalizada em 2005. Argumenta-se, a partir desse debate, que a denominação dos que compõem a El de "institucionalistas britânicos" não parece equivocada, já que o conceito de instituições primárias da sociedade internacional, no rastro da problematização feita por Barry Buzan, permite-nos compreender as práticas intervencionistas mais contemporâneas para além da cisão pluralismo/solidarismo, mantendo, assim, a El fiel ao middle ground.

Palavras-chave: Escola Inglesa; instituições primárias; pluralismo; solidarismo; intervenções humanitárias; R2P.

\begin{abstract}
This paper aims at reassessing the pluralist-solidarist debate, which simultaneously divides and reconvenes the English School (ES) of International Relations, well known for occupying a theoretical middle ground position, from the 1990s on. Following this internal debate whether to follow a pluralist or a solidarist normative position towards international society, the article pays close attention to the contemporary international question that posed the most serious challenge to its middle ground: the humanitarian interventions from the 1990s on and their unfolding in a Responsibility to Protect (R2P) doctrine, institutionalized in 2005. From this internal debate, we will argue that describing ES as a form of "British Institutionalism" is not inconsistent with its main theoretical contributions, especially because the concept of primary institutions of international society, following in Barry Buzan's footsteps, allows us to both understand more contemporary international interventionist practices beyond the unsatisfactory pluralist/solidarist debate and maintain ES anchored to its long-standing middle ground tradition.
\end{abstract}

Keywords: English School; primary institutions; pluralism; solidarism; humanitarian interventions; R2P.

\footnotetext{
* É Professora do Departamento de Relações Internacionais da Pontifícia Universidade Católica de São Paulo (PUC-SP) e Tutora do Programa de Educação Tutorial (PET) de Relações Internacionais da PUC-SP. Doutora em Ciência Política pela USP (2013). Mestre em Ciência Política pela USP (2009). Pesquisadora Visitante na Faculdade de Economia da Universidade de Coimbra (2015/2016). Contato: cmarconi@pucsp. br.
} 


\section{Introdução: o debate pluralismo versus solidarismo e a polarização do middle ground}

O presente artigo argumenta que a aproximação da Escola Inglesa (El)1', primeira abordagem clássica das RI de middle ground², de suas preocupações institucionais permite que a Escola escape da polarização que a acometeu nos anos 1990 quando do debate essencialmente normativo entre pluralistas e solidaristas acerca da legitimidade e moralidade das intervenções humanitárias.

Crê-se que uma compreensão mais precisa do desdobramento da intervenção humanitária, datada dos anos 1990, na Responsibility to Protect (R2P), localizada já nos anos 2000, permite tanto o resgate de uma agenda institucional atrelada à Escola e diluída em seus diversos escritos quanto o fim da cisão que parece ter atacado a Escola em seu cerne: a busca por se sustentar como uma abordagem teórica de via média entre o realismo e revolucionismo³.

Assim, o artigo tem início com a localização e caracterização do debate entre pluralistas e solidaristas, apontando para os contornos morais, sobretudo, do mesmo. Na sequência, expõe-se de forma mais detida como e por que a principal polarização entre pluralistas e solidaristas girou em torno das intervenções humanitárias. Em um terceiro momento do artigo, faz-se uma caracterização do R2P, de modo que, por meio dela, resgate-se os conceitos de instituições internacionais, seja sob a forma de instituições primárias seja sob a forma de instituições secundárias, um tanto diluídos e não uníssonos nos escritos da El4.

Finalmente, já com a compreensão do que significa tratar a El por "institucionalismo britânico", conclui-se que tal agenda institucional, se devidamente aprimorada, pode permitir

1 A Escola Inglesa, segundo Ole Waever, passou por quatro fases principais em sua genealogia. Na primeira, que vai de 1959-1966, destacam-se a fundação do Comitê Britânico para a Teoria Internacional e a publicação de Diplomatic Investigations exatamente em 1966. À época, os teóricos concentravam-se no conceito fulcral de sociedade internacional que caracteriza a Escola. Na segunda fase, que vai de 1966 a 1977, aparece a obra The Anarchical Society, de autoria de Hedley Bull: um de seus principais expoentes. De 1977 até 1992, tem-se a emergência de uma terceira fase da Escola, quando teóricos de segunda geração como John Vincent, Michael Donelan, James Mayall, Alan James, entre outros, prosseguem os escritos da primeira geração, utilizando-se dos conceitos e estruturas de pensamento de Martin Wight e Hedley Bull. Quando Roy Jones publica um texto propondo o encerramento do que ele próprio denominou de Escola Inglesa, ele se pauta no fato de que a repetição dos escritos de primeira geração era uma das características da Escola, o que fazia com que a Escola não mantivesse um pensamento atualizado das RI. Na quarta e última fase, que perdura de 1992 até hoje, Waever demonstra que com os escritos da terceira geração, a El teve possibilidade de se renovar, podendo estabelecer semelhanças e diferenças interessantes com outros aportes teóricos. No ano de 1992, por exemplo, Waever enfatiza que o periódico Millennium dedicou um número especial a essa nova geração da Escola Inglesa. Waever insere Tim Dunne e Nicholas Wheeler como teóricos desta geração da El. Cf. WAEVER, Ole, 1998, pp. 88-89. Este trabalho, vale dizer, tem como referência, justamente, essa quarta fase de escritos da Escola.

2 Por middle ground theory, entende-se aqui as abordagens de RI que justapõem teorias que, por força da narrativa dos Grandes Debates Teóricos, foram posicionadas em extremos opostos. 0 debate Liberalismo versus Realismo, por exemplo, cujo elo parece residir apenas na oposição teórica indicada pelo versus, serve como uma primeira ilustração do que se alega ser a "evolução disciplinar das RI". Entende-se, para efeitos da presente contribuição, que as teorias de middle ground desenvolvem a sua formulação teórica por meio de um continuum teórico, explorando, e quiçá produzindo, distintos pontos de contato entre as teorias.

3 Importante destacar que a El foi a abordagem responsável por qualificar três modelos distintos, mas complementares de compreensão da realidade internacional. Tanto em Wight (2002) quanto em Bull (2002), os modelos foram identificados com três tradições do pensamento internacional e seus expoentes - os conhecidos 3Rs -: Realismo (Maquiavel/Hobbes); Racionalismo (Grotius); Revolucionismo (Kant). A via média se viabiliza tanto pela construção tripartite supracitada quanto pelo fato de o racionalismo estabelecer um ponto de contato simultâneo com os dois Rs adicionais.

4 A pesquisa empreendida por Barry Buzan (2004) será de fundamental importância para nos guiar na recuperação da agenda institucional da El. 
que a Escola se reconcilie com sua identidade fundamental de via média teórica, superando a fase de cisões internas que o debate pluralista-solidarista instaurou ${ }^{5}$.

É sabido que, ao longo de sua existência enquanto Escola, os teóricos britânicos afirmam que os elementos centrais da denominada sociedade internacional - seu construto teórico central - são o compartilhamento de valores pelos seus membros estatais, o reconhecimento de um conjunto de normas e o comprometimento dos Estados com instituições comuns com vistas a sustentar a ordem internacional6.

Todavia, ao longo de seu desenvolvimento nos anos 1990, a El foi dividida em dois grandes grupos que diferiram entre si justamente quanto ao peso do papel e ao escopo dos valores dessa mesma sociedade internacional: os pluralistas e os solidaristas, defendendo, respectivamente, os valores da ordem e da justiça.

Algumas questões, como a de quão satisfatoriamente a estrutura da sociedade internacional contemporânea tem funcionado ou de como certo grau de ordem é obtido na sociedade internacional, movem esse debate. Tradicionalmente, a preocupação central quando se discute tal sociedade internacional tem sido com a ordem?7.

Os teóricos da El buscam avaliar se um tipo específico de normas legais e morais internacionais tem uma maior probabilidade de contribuir para a sustentação dessa ordem, e se, com relação a certos objetivos específicos, a sociedade internacional pautada em Estados soberanos funciona melhor ou é mais adequada do que outro arranjo institucional global possível (LINKLATER; SUGANAMI, 2006, p. 60).

Para responder a essas questões, Hedley Bull contrapõe duas tendências no Direito Internacional Público: a pluralista, mais associada ao século XIX, e a solidarista, associada ao século XX. Essas duas tendências julgam empiricamente o mundo de modo distinto, bem como conformam posições normativas divergentes, mas com amplo potencial complementar, ao ver do presente artigo, acerca do mundo que também seria desejável.

A diferença entre o pluralismo e o solidarismo foi introduzida por Bull em um texto intitulado The Grotian conception of international society, publicado pela primeira vez na obra Diplomatic investigations: essays in the theory of international politics:

Pluralism and solidarism, which at the beginning referred mainly to two contrasting empirical interpretations about whether there was sufficient solidarity or potential solidarity to make law enforcement workable in the existing international society have now come by and

\footnotetext{
5 Registro aqui o devido agradecimento a/ao parecerista ad hoc do presente artigo pela leitura atenta. 0 parecer contribuiu sensivelmente não só para a melhor estruturação do argumento aqui apresentado como do texto em si. Ainda em referência ao parecer, mas também por zelo ao leitor, faz-se importante esclarecer que o argumento aqui contido é de natureza puramente teórica. Àqueles que tenham se proposto à leitura deste artigo com a expectativa de uma análise da doutrina da R2P a partir dos casos e controvérsias mais empíricas a ela relacionados, sobretudo relativas aos casos da Líbia e Síria, sugiro os recentes artigos acadêmicos: AINLEY, 2015; MORRIS, 2013; DUNNE; GIFKINS, 2011.

6 As instituições internacionais que viabilizam, via de regra, a preservação da própria sociedade internacional não são as mesmas na visão de importantes teóricos associados à El. Cf. SCHOUENBORG, 2014, p. 77. Este ponto será demonstrado mais adiante por meio do diálogo com o trabalho de Buzan (2004). Vale antecipar que Hedley Bull, principal expoente da El, inicialmente preocupado com as instituições que garantiriam a preservação da ordem internacional, aponta para cinco instituições-chave: o equilíbrio de poder; 0 direito internacional; a diplomacia; a guerra; as grandes potências.

7 Certamente a obra The Anarchical Society, de 1977, de Hedley Bull, contribuiu para tanto.

8 Posteriormente Alderson e Hurrell (1999) publicaram esse texto de Bull em uma coletânea sobre o autor.
} 
large to be taken to mean two contrasting normative positions, one aiming at a minimalist goal of the orderly coexistence of states, and the other going beyond this to include a more demanding goal of the international protection of human rights standards globally (LINKLATER; SUGANAMI, 2006, p. 6, grifo nosso).

A diferença central entre o solidarismo e o pluralismo, de acordo com o próprio Bull, pode ser apresentada da seguinte maneira:

The central Grotian assumption is that of the solidarity, or potential solidarity, of the states comprising international society, with respect to the enforcement of law [...]. In the conception of international society which stands opposed to the Grotian doctrine the contrary assumption is made that states do not exhibit solidarity of this kind, but are capable of agreeing only for certain minimal purposes which fall short of that of the enforcement of the law. In the view it takes of the area of actual or potential agreement among the member states of international society it may be called pluralist where the Grotian doctrine is solidarist (BULL, 1999, p. 97).

Os três temas que dividem, segundo o mesmo Bull, as duas posições sob análise - o pluralismo e o solidarismo, associadas respectivamente com Oppenheim, expoente do positivismo jurídico, e com Grotius, expoente do jusnaturalismo - são: o lugar ocupado pela guerra na sociedade internacional; as fontes de direito que vinculam os membros da sociedade; e o status conferido aos indivíduos nessa sociedade de Estados (BULL, 1999, p. 97). Esta última questão é a que nos interessa aqui, sobretudo porque levar adiante uma concepção de intervenção em bases humanitárias pode, por vezes, justificar que se assuma o indivíduo como unidade de valor moral fundamental, e exigindo que se reveja o protagonismo do Estado nas relações internacionais.

Ainda acerca desta terceira fonte de divergência, para Oppenheim, os Estados são os únicos sujeitos de direitos e deveres no plano internacional, enquanto para Grotius a existência de uma comunidade humana, na qual justamente os indivíduos estão sujeitos à lei natural, ganha contornos:

For Oppenheim international society is composed of states, and only states possess rights and duties in international Law. Individuals, in his view, may be regarded as objects of international law, as when rights and duties are conferred upon them by international agreements regarding diplomatic immunities or extradition; but these are rights and duties in the domestic law of the country concerned and do not render the recipients of them members of international society own their own rights. [...]. In Grotiu`s system, however, the members of international society are ultimately not states bu individuals. The conception of a society formed by states and sovereigns is present in his thought; but its position is secondary to that of the universal community of mankind, and its legitimacy derivative from it (BULL, 1999, p. 112).

Oppenheim não negava, vale dizer, a existência de normas morais às quais os indivíduos se submeteriam enquanto membros da raça humana. O que ele negava é que esses princípios fizessem parte do sistema de direito positivo aceito pelos Estados e que governam suas relações (LINKLATER; SUGANAMI, 2006, p. 64). 
Grotius via como secundária a sociedade formada por Estados diante da comunidade universal de homens, posto que a legitimidade da primeira derivava da legitimidade da última. Mas a preocupação exclusiva com a sociedade de Estados e uma posição que sustente esta como apenas uma camada do mundo no qual se apresenta a comunidade moral dos homens, não corresponde, necessariamente, à diferença entre pluralistas e solidaristas.

O pluralismo rejeita tentativas de incorporar um conjunto estabelecido de valores na sociedade internacional e não trata de questões como o cumprimento dos direitos humanos e o respeito a princípios democráticos como pertencendo ao escopo da sociedade internacional.

Isto é, não vê como frutífera a incorporação desses valores na sociedade internacional. O escopo dessa sociedade deve ser mínimo e se centrar na ordem, restringindo-se a acordos sobre a soberania, não intervenção e diplomacia (ECKERT, 2006, p. 5). Os pluralistas têm, assim, relegado a uma posição secundária as questões éticas, sobremaneira as questões que orbitam em torno do que seria uma sociedade internacional justa.

Mas o Estado deve ter um direito absoluto de governar seus cidadãos? É nítido que as atrocidades cometidas por Estados soberanos produziram reações dentro da El que vão na direção do solidarismo, questionando quais são os custos de uma ordem pautada em instituições iminentemente pluralistas da sociedade internacional:

If one does not feel very strongly that, for instance, a massive human rights abuse in one country is a serious moral concern for the rest of the humankind, one may tend to be relatively tolerant of an empirical suggestion that there is no sufficient solidarity in the world at present to make it on balance profitable to permit or legalize humanitarian intervention (LINKLATER; SUGANAMI, 2006, p. 63).

É com respeito ao direito de intervenção humanitária que o pluralismo e o solidarismo são contrastados por aquele que sistematizou as principais preocupações solidaristas na década de 1990: Nicholas Wheeler.

Whereas Wheeler uses 'solidarism' partly to denote an empirical judgment about the solidarity or potential solidarity existing in international society, he also uses it to mean a substantive moral doctrine in favor of an international protection of human rights worldwide (LINKLATER; SUGANAMI, 2006, p. 71)

Os pluralistas certamente não aceitam um argumento a favor de uma intervenção humanitária cujo objetivo seja restabelecer os direitos humanos de uma parcela de indivíduos do mundo. Robert Jackson (2003, p. 42), o maior antagonista de Wheeler nos anos 1990, chega a afirmar que o solidarismo envolve um paternalismo objetável, além de comprometer a ordem do sistema internacional:

Whereas Wheeler believes it to be the responsibility of the richer and more powerful states to take care of intolerable miseries experienced in other less successful states, Jackson holds that this is the responsibility of the states in which miseries are experienced (SUGANAMI, 2005, p. 38). 
Assim, pluralistas e solidaristas diferem quanto à imputação da responsabilidade moral no plano das relações internacionais quando alguma situação de injustiça se apresenta, revelando posições divergentes ao avaliar as implicações do princípio da soberania: "For instance, the international norm prohibiting intervention in the domestic affairs of another state not only protects state sovereignty, it also shapes what it means to be a sovereign state" (ALDERSON; HURRELL, 1999, p. 35)

[...] Wheeler assumes humankind, despite its division into sovereign political communities, to form a unified moral community, whereas Jackson sees sovereign political communities to be each responsible for their own citizens ' welfare. Their normative difference may be expressed as a difference concerning what moral implications they each read into the concept of sovereignty (SUGANAMI, 2005, p. 40).

Ao tomar o indivíduo como o sujeito último de preocupação moral, os solidaristas avaliam a emergência de uma sociedade mundial e mais orientada para questões de justiça, mais inclusiva na sua abordagem dos atores da política mundial e menos constrangida em relação às práticas e instituições do passado: "In academic terms, solidarism contributes to the re-convening of the English School in the sense of a research program" (WILLIAMS, 2002, p. 2, mantendo grifo do autor).

Tal programa de pesquisa avança na medida em que também avançam os desafios éticos impostos à realidade das relações internacionais: "The concatenation and pace of change in global material circumstances is reconfiguring traditional questions about the limits of duty, the bound of obligation and the referents for justice" (BO0TH et al, 2000, p. 25).

O sofrimento humano, não importa de onde venha, passa a ser visto como uma grave injustiça e um imperativo para a ação de atores internacionais. Nota-se, portanto, que os escritos de teóricos associados a uma fase primeira da El, inicialmente preocupados com o atributo da ordem, tais como os de Hedley Bull e John Vincent, notoriamente mudam de um enfoque pluralista para um enfoque solidarista ao longo de suas trajetórias acadêmicas.

A questão central deixa, gradativamente, de orbitar em torno da preservação da ordem internacional composta por Estados, passando a ser "[...] what ought morally to be done about injustices in the world of mankind?" (LINKLATER; SUGANAMI, 2006, p. 67).

O Bull tardio revela uma desilusão muito grande com o pluralismo original, pois via que tal posição normativa não estava provendo ordem entre os Estados e que também não se mostrava capaz de prover ordem numa sociedade mundial mais ampla. Historicamente, vale dizer, os interesses da humanidade são agregados e articulados pelos mecanismos da já conhecida sociedade de Estados.

Desse modo, somos obrigados a indagar quais os pontos de vista dos Estados soberanos e das instituições formais, aqui associadas ao conceito de instituições secundárias ${ }^{9}$, para saber quais interesses o mundo pode, no limite, ter: “[...] universal ideologies that are espoused by

9 Brevemente esclareceremos as definições tanto de instituições primárias quanto secundárias na literatura da Escola Inglesa, sendo este justamente $\mathrm{o}$ aspecto que nos permitirá denominar a El de institucionalismo britânico. 
states are notoriously subservient to their special interests, and agreements reached among states notoriously the product of bargaining and compromise rather than of any consideration of the interests of mankind as a whole (BULL, 2002, p. 82).

É sabido que o desenvolvimento, por exemplo, da tradição liberal das democracias ocidentais está associado a um forte compromisso com a causa dos direitos humanos individuais em escala mundial, mas ainda residem divergências entre os diferentes Estados sobre o que significam esses direitos e quais são prioritários ${ }^{10}$ :

The new international law and morality of human rights is dogged by a lack of consensus among the main groups of states about the meaning of these rights and the priorities among them: the primacy attached to in the Western world to civil and political rights, as opposed to economic and social rights, to rights enjoyed by individual person as opposed to the rights of groups" (BULL, 1999, p. 221, grifo nosso).

A falta de consenso entre os Estados-parte da sociedade internacional não se restringe somente à dificuldade de encontrar uma concepção de direitos humanos que seja universalmente válida, mas também se verifica em como lidar com os perigos que a sociedade humana tem enfrentado. A posse de armas nucleares por alguns Estados, por exemplo, ou ainda as dificuldades de se chegar a um equilíbrio populacional frente à escassez de recursos básicos, ou mesmo de como lidar com os impactos do aquecimento global, compõem o cenário de dissonâncias.

Acrescenta-se a isso o fato de inexistirem instituições adequadas para autorizar prontamente algum tipo de ação nesses casos. Os órgãos políticos do denominado Sistema da Organização das Nações Unidas (ONU), por exemplo, não possuem legislatura mundial, pois representam os Estados, ou melhor, os governos, e não os indivíduos ${ }^{11}$.

A questão contemporânea das relações internacionais aqui escolhida por contemplar na essência a dicotomização do middle ground britânico aqui apresentada - entre manter a ordem entre os Estados soberanos pautada na coexistência entre eles ou promover princípios de justiça que façam referência ao homem na condição de unidade moral fundamental das relações internacionais - são as intervenções humanitárias, principalmente porque a questão não se reduziu aos anos 1990, tendo sido revista mais proximamente pela denominada Responsibility to Protect.

10 Deve-se, todavia, ressaltar a controvérsia presente nessa afirmação. Os Estados Unidos, por exemplo, não ratificaram documentos fundamentais do regime internacional de direitos humanos, alegando,sobretudo, que os mesmos entram em choque com a sua soberania nacional. Alguns exemplos de não ratificação por parte dos Estados Unidos são o Pacto Internacional sobre Direitos Sociais, Econômicos e Culturais, adotado em 1966, o Primeiro e Segundo Protocolos Opcionais ao Pacto Internacional de Direitos Civis e Políticos, adotados respectivamente em 1966 e 1989, a Convenção sobre os Direitos das Crianças, adotada em 1989, bem como seus dois protocolos opcionais, a Convenção para a Eliminação de todas as Formas de Discriminação contra a Mulher. adotada em 1979, bem como seu protocolo opcional adotado em 1999, a Convenção Internacional sobre a Proteção aos Direitos dos Trabalhadores Migrantes e Membros de suas Famílias, adotada em 1990, e o Estatuto de Roma para o Tribunal Penal Internacional, adotado em 1998

11 Uma importante posição cética, em claro contraste com esta aqui apresentada, e que nos provoca a pensar que tais organizações internacionais não seriam capazes de suprir o denominado déficit democrático, é de Robert Dahl. Cf. DAHL, 2001. 


\section{As intervenções humanitárias pela óptica da Escola Inglesa}

Segundo a Carta da Organização das Nações Unidas (ONU), afirmar que uma situação representa uma ameaça para a paz e segurança internacionais é a única maneira de legitimar uma intervenção no território nacional de um outro Estado. Esse mecanismo produz, todavia, grande receio por parte dos que enxergam nessa prática a possibilidade de abertura de precedentes para intervenções humanitárias unilaterais e/ou indiscriminadas, o que facilmente erodiria a ordem internacional.

Esse argumento pode ser verificado na obra de um dos mais negligenciados teóricos da El - John Vincent ${ }^{12}$ - Nonintervention and International Order, de 1974, momento em que ele afirmava que o princípio da não intervenção era um meio necessário de garantir a ordem internacional.

Todavia, nota-se uma aproximação deste último autor com uma noção mais espessa de ética nas relações internacionais, refletida fortemente em Human Rights and International Relations, de 1986, publicada alguns anos mais tarde. Nesta obra, Vincent afirma que os direitos humanos desempenham um papel crucial na decisão sobre a legitimidade de um Estado na condução de suas relações internacionais. Apenas a soberania não é suficiente para legitimar a conduta de um Estado. Ele deve agir domesticamente de modo tal que não ultrapasse os direitos dos indivíduos e grupos que estão sob a sua jurisdição territorial.

Para Suganami (2001), o livro de Vincent de 1986 é mais explicitamente normativo que qualquer outro que o tenha precedido na El, objetivando responder em que medida as intervenções humanitárias se tornaram uma prática legítima na sociedade internacional.

A tendência dos adeptos do mainstream realista é defender que os Estados são juízes e júri em suas próprias cortes, porque o Direito Internacional carece de autoridade para criar obrigações vinculantes. Mas em matéria de direitos humanos, a legalidade não pode bastar, pois o direito pode se submeter a interesses particulares e não exprimir uma vontade geral. Pode haver, portanto, um vácuo entre legitimidade e legalidade. Isso se verifica quando certas regras legais não são vistas positivamente do ponto de vista moral pelos cidadãos ${ }^{13}$.

Mas também pode haver certas ações que são morais, mas não legais. Por esse motivo, não se pode abdicar de investigar também a legalidade das intervençõeshumanitárias, que parecem desafiar os princípios westfalianos de não intervenção e não uso da força nas relações internacionais e traduzem de maneira clara o dilema moral do que se deve fazer com os outsiders que são submetidos às crueldades mais diversas pelos seus governantes. Assim, os membros da sociedade internacional veem-se diante de um trade-off entre interferência em assuntos internos de um país e acusações de indiferença moral diante do sofrimento humano indiscriminado.

Acrescenta-se a esse fato a existência de um gap entre os compromissos normativos no plano internacional no que tange à proteção dos direitos humanos e os instrumentos e

\footnotetext{
12 Alguns aspectos da obra de John Vincent foram mais detidamente explorados em Marconi, 2015.

13 John Vincent (1986), afirma que as leis raciais na África do Sul durante o regime do apartheid e as leis arianas durante o Nazismo são exemplificações de regras legais vistas como imorais pelos seres humanos.
} 
prerrogativas que permitem que os governos abusem de sua autoridade frente aos direitos daqueles que são seus próprios governados e deveriam ser por eles protegidos.

É conforme o século XX avança que a conduta dos governos em relação aos seus cidadãos vai se tornando objeto de questionamento e, eventualmente, criando precedentes para a intervenção:

For the first time in the history of modern international society, the domestic conduct of governments was now exposed to scrutiny by other governments, human rights non-governmental organizations (NGOs), and international organizations. But the new human rights regime was severely limited by the weaknesses of its enforcement mechanisms (WHEELER, 2002, p. 1, grifo nosso).

Mas como a sociedade de Estados legitimaria o uso da força contra Estados que violam sistematicamente os direitos humanos? Para Wheeler: "[...] legitimacy is constitutive of international action. [...]. My contention is that state actions will be constrained if they cannot be justified in terms of plausible legitimating reasons" (WHEELER, 2002, p. 4).

Até que ponto as intervenções humanitárias pertencem ao escopo das razões legítimas da justificativa do uso da força? O argumento contrário à autorização de intervenções humanitárias pauta-se, usualmente, na crença de que a ação de um Estado nesses casos sempre estará movida por uma noção de interesse definidos em termos de poder. Wheeler, enquanto expoente da concepção solidarista, discorda de Carr. ${ }^{14}$, que, ainda que com ressalvas, figura entre os teóricos clássicos da El: "Carr contended that theories of international morality or legitimacy are always 'the product of dominant nations or groups of nations'” (WHEELER, 2002, p. 6, mantendo grifo do autor).

É pautada nessa crença ecoada de Carr que a vertente pluralista da teoria da sociedade internacional define a intervenção humanitária como uma violação das regras cardinais de soberania, não intervenção e não uso da força: "States and not individuals are the principal bearers of rights and duties in international law, and pluralists are skeptical that states can develop agreement beyond a minimum ethic of coexistence" (WHEELER, 2002, p. 11). Essa concepção encapsula a noção de moralidade aos Estados, posto que

[...] it takes states not only to be capable of moral responsibility but also, in its classic form, to be the only bearers of rights and duties in the international society which together they form. Individuals and groups other than states have access to this international society only through the agency of their states (VINCENT, 1986, p. 113).

O princípio da não intervenção é capaz de prevenir que indivíduos e grupos entrem no caminho da relação entre os Estados: "It is within states that a platform of order is established on which the justice we associate with the notion of human rights might be based. So anything that threatens order threatens also the possibility of achieving justice" (VINCENT, 1986, p. 114).

14 E. H. Carr é inadvertidamente tomado como o precursor da perspectiva teórica realista, ao ver da presente contribuição. Aqui vemos Carr como quem, pela primeira vez, busca uma perspectiva de middle ground ao sugerir, ainda no período do entreguerras, para uma orientação teórica que evitasse os extremos da utopia e realidade, isto é, respectivamente uma posição utópica ingênua e uma posição realista estéril. Cf. CARR, 2001. 
Assim, a intervenção é ilegítima enquanto uma infração às soberanias estatais, já que os interesses que movem o interventor são sempre os seus e não preocupações humanitárias pretensamente gerais. 0 pluralismo reconhece, portanto, os limites da solidariedade no plano internacional:

If international society is accurately described as composed of sovereign states, enclosing different political systems, guarding them jealousy and always on the look-out for the next threat to them, then we may expect among its members two general attitudes towards the question of intervention. The first is the doubt about the motives of interveners. The second is one of skepticism about any good outcome of intervention [...] the attitude would be that intervention is unlikely to produce any good result since the vehicle of interference, bringing in outsiders, is itself morally disagreeable. [...]. Moreover, any principle of humanitarian intervention would issue a license for all kinds of interference (VINCENT, 1986, p. 114).

Dois argumentos fortes para a não intervenção são: primeiro, a não intervenção deriva dos direitos fundamentais dos Estados; segundo, a não intervenção é o corolário do princípio da autodeterminação (VINCENT,1986, p. 115).

O que a não intervenção permite é, portanto, uma posição moral pluralista, que aceita a diversidade dentro dos Estados: "It recognizes the foreignness of foreigners. It can concede that cultural differences are in some degrees morally relevant" (VINCENT, 1986, p. 117). A aceitação do pluralismo vem, vale destacar, menos da satisfação moral com a sociedade de Estados, e mais da preocupação acerca das consequências de uma posição alternativa intervencionista (VINCENT, 1986, p. 118):

If the central idea of the 'morality of states' is that states should be desensitized to each other's domestic wrongdoings in the interest of order among them, the central idea of cosmopolitanist morality is to heighten the sensitivity of people in one place to wrongs done in another in the interest of the achievement of global justice (VINCENT, 1986, p. 118).

As críticas acerca dessa moralidade prudencial do Estado advêm fundamentalmente de dois argumentos: primeiro, os Estados não se parecem com os indivíduos na sua singularidade moral e, segundo, os grupos pretensamente singulares chamados Estados não podem ter antecedência moral sobre os indivíduos que o compõem. Essas são as críticas daqueles que investem numa abordagem que flexibiliza o estadocentrismo.

Apoiar-se no pertencimento exclusivista a uma comunidade estatal é sustentar o sistema usual de obrigações e isso não necessariamente é o correto, pois não se pode supor que as questões morais mais substantivas se limitem ao Estado e a uma sociedade exclusivamente deles composta: "Subsistence in the face of starvation, security in the face of arbitrary violence: these are issues which currently confront mankind, and neither of them can be met within the framework of the society of states" (VINCENT, 1986, p. 116).

O solidarismo se apresenta, na contramão do pluralismo, como uma "[...] voice that looks to strengthen the legitimacy of international society by deepening its commitment to justice" (WHEELER, 2002, p. 11) e que contempla a doutrina da intervenção, pois obriga uma resposta 
por parte dos outsiders se a conduta de um Estado desafiar a consciência humana: "The failure of a government of a state to provide for its citizens' basic rights might now be taken as a reason for considering it illegitimate" (VINCENT, 1986, p. 127).

Situações concretas de gravíssimas violações de direitos humanos, e que indicariam para um dever de intervenção, colocam, vale dizer, os imperativos da ordem e da justiça como objetivos a serem compatibilizados, ao nosso ver. A guerra na Bósnia, por exemplo, caso clássico de intervenção, traz à tona não só a necessidade de contornar uma situação de injustiça, mas fundamentalmente a questão da sustentação da ordem internacional. Essa mesma preocupação com a ordem não aparece, todavia, no momento em que se verifica o genocídio em Ruanda, posto que uma crise humanitária nesse país africano não se configurava como uma ameaça à estabilidade global, tal como um genocídio nos Balcãs: "Whatever the limits of solidarism [...] the case of the genocide in Rwanda in 1994 highlights the paucity of cosmopolitan moral awareness when it comes to human suffering in Africa" (DUNNE; WHEELER, 1996, p. 103).

Um igual tratamento das emergências humanitárias que se verificam nas mais diferentes partes do globo é o desafio maior que se apresenta para uma sociedade internacional menos estadocêntrica e mais inclusiva no que diz respeito aos indivíduos. A doutrina da Responsibility to Protect parece ecoar as preocupações solidaristas quando fundamenta as intervenções humanitárias em bases mais universalistas, promovendo uma inflexão quanto aos pilares tradicionais da ordem internacional.

É nesse sentido que apresentamos a seguir uma problematização preliminar acerca do quanto o R2P, institucionalizado em 2005 pela ONU, permite que se retome a agenda institucional da El tanto por parecer concentrar contemporaneamente a discussão acerca das bases morais da aprovação de práticas intervencionistas ${ }^{15}$, tornando-se uma prática institucionalizada de uma sociedade internacional que expande suas fronteiras morais, quanto por evitar que as contribuições de importante Escola para esta questão sejam dadas apenas a partir dos ecos da polarização do pluralismo versus solidarismo.

\section{A Responsibility to Protect $(R 2 P)$ enquanto doutrina contemporânea da intervenção humanitária: um resgate dos conceitos de instituições internacionais na El}

A proposta envolvida sob a rubrica do $R 2 P$ revela contemporaneamente mais uma inflexão quanto ao entendimento da soberania estatal e do dever de não intervenção que a acompanha, sugerindo para um aprofundamento de uma concepção ética solidarista e para a busca de um consenso que não se obteve em torno das intervenções humanitárias dos anos 1990.

15 Ainda no sentido de justificar a presente contribuição, faz-se oportuno destacar que, no Encontro Anual da International Studies Association de 2014, identificou-se a presença de artigos que se propunham a analisar as intervenções humanitárias à luz do $R 2 P$ e que foram patrocinadas pelas denominadas English School Session e International Ethics Session, duas sessões que cedem espaço para pesquisas de teor normativo. Cf. http://www.isanet.org/Portals/0/Media/Conferences/Toronto2014/Toronto\%202014\%20 -\%20Full\%20Program.pdf. 
Foi em 2004 que a Organização das Nações Unidas (ONU) assumiu em suas práticas a doutrina da Responsability to Protect ou R2P, como se disseminou ${ }^{16}$. Tal doutrina se fortaleceu como uma resposta às exortações feitas por Kofi Annan, então Secretário-Geral das Nações Unidas, sobre o dilema soberania versus direitos humanos em seu Millennium Report "[...] if humanitarian interventions is, indeed, an unacceptable assault on sovereignty, how should we respond to a Rwanda, to a Srebenica - to gross and systematic violations of human rights that effect every precept o four common humanity?" (A/50/2000, parágrafo 217).

Curiosamente, numa tentativa de apontar possíveis soluções para esse dilema, a intitulada International Comission on Intervention and State Sovereignty (ICISS), se estabelece em 2000. Trata-se de comissão de caráter ad hoc, subsidiada principalmente pelo governo canadense e, em segunda instância, pelos governos do Reino Unido, Suíça e algumas fundações internacionais, e composta por doze comissários ${ }^{17}$. Assemelhando-se em alguma medida a iniciativas anteriores de se desenhar novas regras internacionais como as que se viu emergir em torno da área temática ambiental a partir da Brundtland Comission on Environment and Development, a Comissão era desvinculada do Sistema ONU e parecia se comportar tal como uma comunidade epistêmica (1992)18.

Em 2001, ano em que se previa o seu fim, a ICISS divulgou um relatório sistematizando do que se tratava a R2P e apontou para uma ressignificação da soberania. A proposta da referida Comissão era a de reconciliar as noções antagônicas de soberania e intervenção diante das denominadas graves violações de direitos humanos ${ }^{19}$. É nesse sentido que se propõe a transição do paradigma tradicional da "[...] sovereignty as control to sovereignty as responsibility in both internal functions and external duties" (ICISS, 2001, p. 13). Assim, a responsabilidade de intervir parece se converter em um dever por parte da sociedade internacional, deixando de se portar como um direito alvo de avaliações circunstanciais de alguns Estados.

16 A institucionalização definitiva do R2P no âmbito da ONU deu-se no High-level Panel on Threats, Challenges and Change, 2004. Cf. A/59/565. Em 2005, no Relatório do Secretário Geral da ONU - In larger Freedom - tal instituição recebe endosso e, finalmente, na Cúpula Mundial da ONU, também datada de 2005, os Estados-Membros da Organização aceitam o R2P como uma obrigação. Ver A/59/2005.

17 A denominada ICISS se constituiu em resposta ao chamado do Secretário Geral à época, Kofi Annan, por ocasião da Cúpula do Milênio de 2000 da ONU. 0 governo canadense concentrou esses esforços de resposta, reunindo 12 membros de distintas áreas sob a liderança dos denominados "Co-chairs": Gareth Evans, ex-ministro de relações exteriores da Austrália e presidente do International Crisis Group e o argelino Mohamed Sahnoun, então consultor especial do Secretário-Geral da ONU. Vale ainda dizer que a Comissão contou com a consultoria de um Advsory Board internacional que reunia lideranças políticas de diferentes Estados, presidentes de fundações diversas e até pesquisadores de alguns centros de referência acadêmica. Cf. https://www.unitar.org/ny/sites/unitar.org. ny/files/69974_eng_175_Ipi.pdf.

18 A noção de comunidades epistêmicas sugere que uma forma decisiva de poder é o monopólio de informações e, sobretudo, de conhecimento quando se pensa em formular e coordenar políticas. Tal conceito foi consagrado por Haas (1992, p. 3): "An epistemic community is a network of professional with recognized expertise and competence in a particular domain and an authoritative claim to policy-relevant knowledge within thatdomain or issue-area. Although an epistemic community may consist of professional from a variety of disciplines and backgrounds, they have (1) a shared set of normative and principled beliefs, which provide a value-based rationale for the social action of community members; (2) shared causal beliefs, which are derived from their analysis of practices leading or contributing to a central set of problems in their domain andwhich then serve as the basis for elucidating the multiple linkages between possible policy actions and desired outcomes; (3) shared notions of validity - that is, intersubjective, internally defined criteria for weighing and validating knowledge in the domain of their expertise; and (4) a common policy enterprise - that is, a set of common practices associated with a set of problems to which their professional competenceis directed, presumably out of the conviction that human welfare will be enhanced as a consequence".

19 É possível perceber que a ativação da denominada R2P ocorre quando graves violações de direitos humanos estão em jogo. Isso se afirma por se ver contemplado no relatório de 2001 tanto a noção de "large scale loss of life" quanto a noção de "large scale ethnic cleansing", remetendo-nos de automático para os terrenos político-sociais em que atrocidades são praticadas e não contam com a vontade manifesta do governo de contê-las ou indicam para a incapacidade do mesmo de fazê-lo. 
O relatório da ICISS organiza em quatro princípios core a responsabilidade de proteger: os princípios básicos, os fundamentos, os elementos e as prioridades. Os princípios básicos centram-se na ideia de que a soberania de um Estado implica na responsabilidade de proteção dos seus cidadãos. Todavia, nos casos em que "[...] a population is suffering serious harm, as a result of internal war, insurgency, repression or state failure, and the state in question is unwilling or unable to halt oravert it, the principle of non-intervention yields to the international responsibilityto protect (ICISS, 2001, p. 11, grifo nosso).

Quanto aos fundamentos, o maior destaque é dado ao dever do Conselho de Segurança das Nações Unidas (CSONU) de manter a paz e a segurança internacionais, considerado o órgão legal e legítimo para decisões ligadas à R2P. Além disso, a ICISS (2001, p. 11) fundamenta a sua doutrina nas "[...] specific legal obligations under human rights and human protection declarations, covenants and treaties, international humanitarian law and national law", isto é, na hard law disponivel em matéria de direitos humanos.

Sobre os elementos, há três responsabilidades abarcadas pela doutrina do R2P: responsabilidade de prevenir, responsabilidade de reagir e responsabilidade de reconstruir e que recaem não só sobre os Estados membros, mas também sobre a etérea comunidade internacional20. Os três elementos parecem dialogar com uma interpretação das fases de um conflito: pré, durante e pós conflito, respectivamente, ou ainda com os mecanismos tradicionais da própria ONU para lidar com as realidade de conflito: peacemaking, peacekeeping e peacebuilding.

No que tange às prioridades, fica claro que, dos três elementos, o primeiro é o que precisa ser sobrevalorizado. Em outras palavras, a prevenção deve ser esgotada antes de se lançar mão de medidas intrusivas e de caráter coercitivo (ICISS, 2001, p. XI).

Tendo aqui sido expostos os principais elementos constitutivos do que parece ter potencial para se consumar como uma prática emergente do século XXI - o R2P - resgataremos as noções de instituições primárias e secundárias da sociedade internacional presentes na El a fim de avaliar o lugar das intervenções humanitárias e da própria doutrina da Responsabilidade de Proteger para além da polarização provocada pelo debate interno à Escola que aqui foi exposto.

Em última instância, o que se pretende avaliar nesta última sessão do artigo é em que medida a problematização sobre as instituições internacionais feita pela El nos permite ir além da polarização do middle ground entre pluralistas e solidaristas em torno das intervenções, avançando para o que o próprio R2P parece sugerir quando clama para si um dever de intervenção e, por extensão, compatibiliza instituições tradicionalmente antagônicas: a soberania e a intervenção.

20 Sobre a pouca definição do relatório da ICISS acerca do que consistiria a denominada comunidade internacional, Focarelli (2008, p. 198, mantendo grifo do autor) afirma que: "The report does not draw the line between the action of the state concerned and the action of the international community, nor does it explain what should be properly meant by international community. It only says that the United Nations is "unquestionably the principal institution for building, consolidating and using the authority of the international community"” 


\subsection{As instituições primárias e secundárias da sociedade internacional: o status de institucionalistas britânicos 21}

"We students of international affairs need a better theory of institutions'. So said Robert Keohane, who is a principal in recent discussions of institutions and their importance" (ONUF, 2002). É com esta inquietação ainda presente no desenvolvimento da área de Relações Internacionais que aqui é proposto que se vejam os teóricos da El como institucionalistas britânicos e como uma Escola que pode oferecer ferramental conceitual22 para irmos além do debate sobre se as instituições importam meramente: "It would help us understand the ways in which insitutions possibly matter by telling us how they come about, have the properties that they do, and como to be used" (ONUF, 2002, p. 211, mantendo grifo do autor).

Dessa forma, os conceitos de instituições primárias e secundárias são objeto desse esforço com vistas a: (1) resgatar a agenda institucionalista tão rica da Escola em questão; (2) localizar preocupações a respeito de como as instituições surgem e quais as possibilidades de serem importantes; e, finalmente (3) indicar uma fonte de preocupação comum dos escritos da El ao longo de sua trajetória, mesmo quando se verifica tamanha cisão na Escola nos anos 1990 por força dos impasses entre pluralistas e solidaristas em torno das intervenções humanitárias.

Buzan (2004, p. 164), grande responsável por empreender a pesquisa que apontará de forma incontroversa para o lugar central das instituições desde o que aqui assumimos como a gênese do Comitê Britânico até os dias atuais, diz que: "In common usage, 'institution' can be understood either in quite specific terms as 'an organisation or establishment founded for a specific purpose', or in more general ones as 'an established custom, law, or relationship in a society or community'".

Estes sentidos separam as noções de instituições secundárias e primárias, respectivamente. Enquanto as primeiras nos conectam diretamente aos arranjos institucionais formalmente concebidos e contam com amplo debate a seu respeito nas RI, as últimas representam práticas fundamentais e duráveis e que mais evoluem a partir do comportamento dos atores internacionais do que são racionalmente desenhadas por eles, constituindo, portanto, a própria sociedade internacional23.

Buzan (2004, p. 171-174, grifo nosso), em sua investigação, ainda elenca as instituições candidatas a instituições primárias por teóricos da El cujas obras ele rastreia, exortando que mais pesquisa seja feita na direção de vermos nas instituiç̧ões desse tipo um papel de coesão a ser desempenhado pela Escola:

21 Tal caracterização da El como "institucionalistas britânicos" apareceu na contribuição de Hidemi Suganami, 2003.

22 Tal como sugere Keene (2009), ainda que o pluralismo teórico e metodológico da El impeça que ela seja identificada a partir de um ou de alguns métodos específicos, a ambição conceitual que caracteriza a Escola nos permite ir além de conceitos meramente descritivos.

23 Já na obra de Wight (2002), parecia haver uma preferência e preocupação maior com instituições que fossem identificadas com comportamentos-padrão organizados, integrados e duradouros, por meio dos quais o controle social se daria e as necessidades sociais seriam atendidas. Vale ressaltar que o fato desta distinção entre instituições primárias e secundárias importar desde a primeira fase da El está contemplado no capítulo intitulado "English School and Institutions: British Institutionalists", escrito por Schouenborg, e que compõe a obra recém-publicada Guide to the English School of International Relations (2014). 


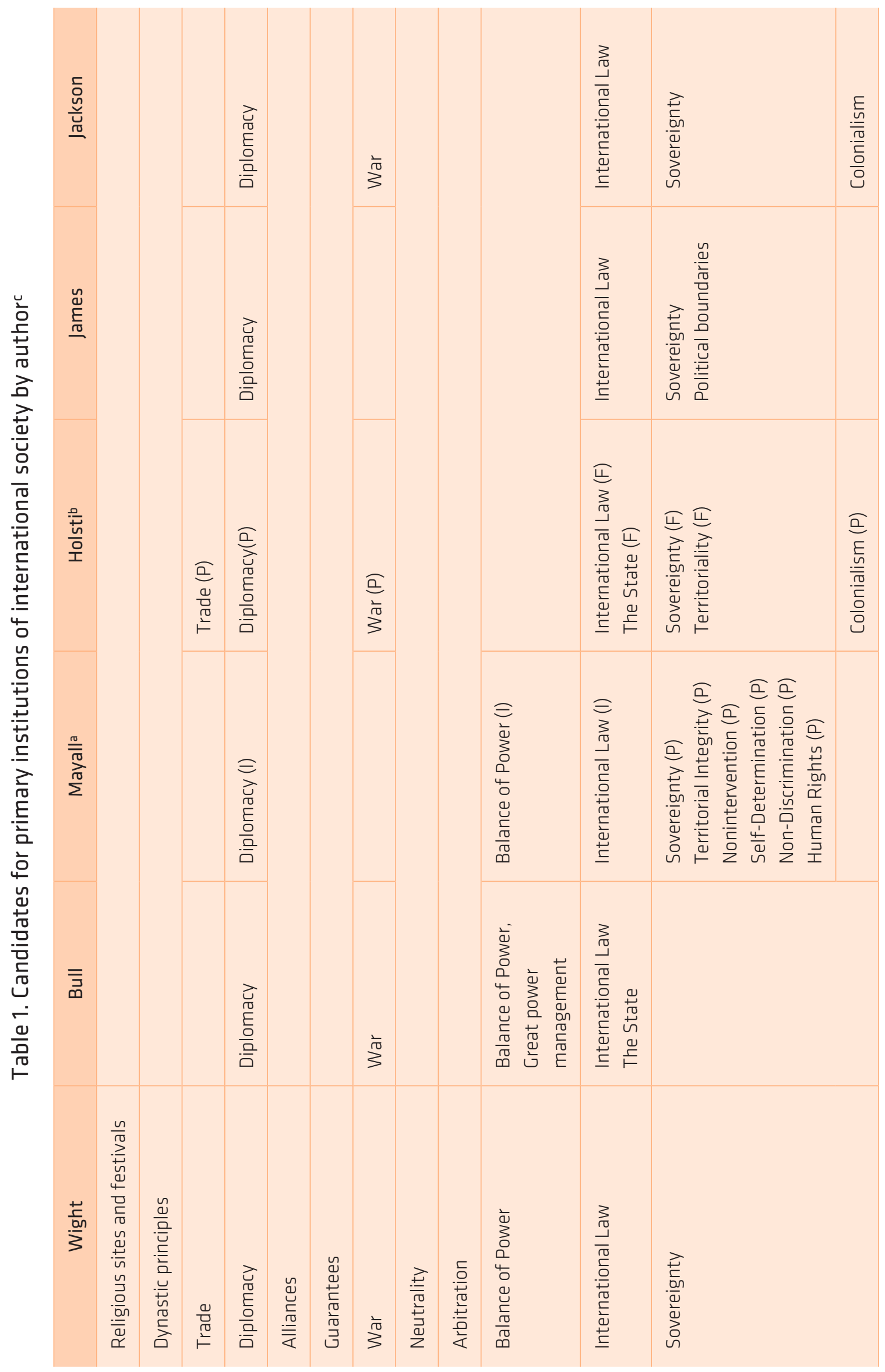


As instituições primárias, tal como vemos na tabela acima (BUZAN, 2004), vão muito além da própria soberania, chegando a incorporar padrões de comportamento outros, a depender do teórico da El, tais como o comércio, a arbitragem, os direitos humanos ou mesmo a não discriminação.

O surgimento e o desenvolvimento de tais instituições não são contíguos. Isto é, enquanto algumas instituições acompanham a própria configuração primeira de sociedade internacional - uma sociedade internacional circunscrita a poucos países europeus -, outras instituições se conformam mais recentemente, como é o caso dos próprios direitos humanos ou da não discriminação.

Vale ainda, com referência ao mapeamento feito por Buzan (2004) e consolidado na tabela acima, reconhecer para fins a que se pretende o presente artigo que a não intervenção aparece de forma explicitada como uma instituição primária apenas na obra de James Mayall24. Tal diagnóstico nos permitiria, quiçá, reconhecer espaço para a compatibilização da soberania com um dever de intervir preconizado pelo R2P.

Buzan, com a expectativa de hierarquizar as instituições supracitadas a partir das tantas contribuições ditas britânicas, identifica a necessidade de subdividílas em dois tipos - as instituições primárias master e as instituições primárias derivative. Segundo ele (2004, p. 176, grifo nosso): "The summary also suggests a recurrent desire to differentiate primary institutions into some sort of hierarchy between the deeper and more constitutive, and the less deep and more procedural".

Tem-se, assim, a tabela abaixo, também extraída da contribuição de Buzan (2004), que não pretende esgotar, mas sim apontar para as dificuldades de se hierarquizar as instituições primárias, não só porque tais instituições se diferenciam de teórico para teórico, mas principalmente porque, em alguma medida, as próprias instituições primárias podem se contradizer:

24 Professor Emérito do Departamento de Política e Estudos Internacionais da Universidade de Cambridge. Cf. http://www.polis.cam. ac.uk/Staff_and_Students/professor-james-mayall. Último acesso em 05 de julho de 2015. 
Table 2. Thenested hierarchy of international institutions

\begin{tabular}{|c|c|}
\hline \multicolumn{2}{|c|}{ Primary Institutions } \\
\hline Master & Derivative \\
\hline Sovereignty & $\begin{array}{l}\text { Non-intervention } \\
\text { International law }\end{array}$ \\
\hline Territoriality & Boundaries \\
\hline Diplomacy & $\begin{array}{l}\text { Messengers/diplomats } \\
\text { Conferences/Congresses } \\
\text { Multilateralism } \\
\text { Diplomatic language } \\
\text { Arbitration }\end{array}$ \\
\hline Balance of power & $\begin{array}{l}\text { Anti-hegemonism } \\
\text { Alliances } \\
\text { Guarantees } \\
\text { Neutrality } \\
\text { War } \\
\text { Great power management }\end{array}$ \\
\hline Equality of people & $\begin{array}{l}\text { Human Rights } \\
\text { Humanitarian intervention }\end{array}$ \\
\hline Inequality of people & $\begin{array}{l}\text { Colonialism } \\
\text { Dynasticism }\end{array}$ \\
\hline Trade & $\begin{array}{l}\text { Market } \\
\text { Protectionism } \\
\text { Hegemonic stability }\end{array}$ \\
\hline Nationalism & $\begin{array}{l}\text { Self-determination } \\
\text { Popular sovereignty } \\
\text { Democracy }\end{array}$ \\
\hline
\end{tabular}

Um exemplo de contradição seria, por exemplo, o quanto o comércio pautado no livremercado impacta a soberania (BUZAN, 2004, p. 184). Ou, ainda, como instituições que há muito clamam entre si uma coesão intrínseca - soberania, territorialidade, equilíbrio de poder ${ }^{25}$ poderiam ser impactadas por instituições que emergem de novas formas de interação entre os Estados ou mesmo entre novos atores, tal como parece ser o caso da própria intervenção humanitária:

There is endless scope for dispute as to what extent new institutions (the market, or human rights) change either the game or the players, and over what time periods they do so. In terms of the discussion [...] the question is: does solidarism change the game of states, and at what point do those changes add up to a new game for which the name 'game of states' is no longer appropriate? (BUZAN, 2004, p. 181).

25 Essa coesão intrínseca entre as instituições citadas pode ser vista nos ditos pluralistas quando estes sintetizam na ordem o valor supremo da sociedade internacional. 
Compartilhamos com Buzan o entendimento de que a tensão entre as instituições primárias é força propulsionadora do desenvolvimento da sociedade internacional (BUZAN, 2004, p. 186).

Desse modo, seria importante analisar se e como a emergência de um dever de intervenção, tal como vimos contido na doutrina do R2P, impacta na instituição primária que, dentre todas as candidatas, é aquela que mais destaque tem nas distintas contribuições da El: a soberania. Ou ainda se a intervenção humanitária, importante instituição primária derivative da instituição master igualdade entre os povos, fortalece-se como prática constitutiva da sociedade internacional na medida em que a doutrina do R2P ganha contornos mais claros².

\section{Considerações finais}

Pretendeu-se aqui apontar que a polarização do middle ground britânico fundamentalmente entre pluralistas e solidaristas em torno das intervenções humanitárias e do posterior desenvolvimento da doutrina do R2P não é um ponto de não retorno para a própria Escola que tem por vocação a virtude da via média.

A busca pelo papel da El na elaboração de conceitos que não são meramente ferramental descritivo para e das relações internacionais permitiu-nos revelar um arcabouço conceitual presente em seus escritos muito pouco explorado tanto internacionalmente quanto no Brasil. Trata-se da noção mais ampla de instituições e da noção mais específica de instituições primárias, destacadas nos esforços de pesquisa de Buzan.

O resgate de uma agenda institucionalista a partir da El permite-nos afastar a ideia de instituições apenas como arranjos formais, racionalmente desenhados e sobre os quais recai a dúvida sobre se e em que medida importam, aproximando-nos do entendimento de que as instituições são conformadas pelas próprias ações políticas dos atores internacionais.

Tal entendimento leva à compreensão da sociedade internacional menos como um domínio estático e mais como viabilizadora de novos comportamentos que, mesmo que contraditórios em uma primeira análise, portam-se como força propulsionadora do próprio desenvolvimento da sociedade internacional.

Dessa perspectiva, a migração de uma doutrina da intervenção humanitária para a doutrina do R2P permitiu-nos analisar de que modo as denominadas instituições primárias podem, inclusive, recombinar-se, tal como é o caso da soberania e da intervenção, por força da emergência da responsabilidade de proteger indivíduos expostos a graves violações de direitos humanos dentro dos limites fronteiriços do próprio Estado:

[...] the responsibility to protect is indeed the subject of an 'emerging guiding principle' [...] inasmuch as it is 'supported by a wide variety of legal sources', including 'fundamental natural law principles', the UN Charter's provisions on human rights, the numerous existing treaties on human rights and on international humanitarian law and the Statute of the International Criminal Court [...] (FOCARELLI, 2008, p. 195).

26 Para mais informações sobre a ativação do R2P, ver o o caso líbio em ICRToP, online. 
O tratamento da agenda institucionalista dos britânicos oferece, assim, condições de, ao ir além da polarização inerente ao debate pluralismo-solidarismo dos anos 1990, compreender como determinadas instituições internacionais primárias se modificam, surgem e passam a se relacionar, de forma mais ou menos controversa, com as instituições primárias preexistentes, sem que isso signifique o seu descarte ou ainda sem que isso signifique uma acomodação automática.

Escapa-se, desse modo, da irredutível escolha entre a preservação de uma ordem internacional ou a evolução moral certeira da sociedade internacional na direção do que é justo, colocada pelo debate interno à Escola dos anos 1990, e abre-se uma agenda a partir da qual a El possa se reconciliar com o middle ground por ela mesma fundado e contribuir para a reflexão teórica mais abrangente sobre as instituições internacionais menos formais, mas não menos relevantes: as instituições primárias.

\section{Referências bibliográficas}

A/50/2000. We the peoples: the role of the UN in the 21st century. Report of the Secretary General. 2000. Disponivel em: http://unpan1.un. org/intradoc/groups/public/documents/un/unpan000923.pdf. Último acesso em 30 de maio de 2015.

A/59/565. Note by the Secretary General. 2004. Disponivel em: http://www2.ohchr.org/english/bodies/ hrcouncil/docs/gaA.59.565_En. pdf. Último acesso em 30 de maio de 2015.

A/59/2005. In larger Freedom: towards development, security and human rights for all. Report of the Secretary General. 2005. Disponivel em: http://www.un. org/en/ga/search/view_doc.asp?symbol=A/59/2005. Último acesso em 30 de maio de 2015.

AINLEY, Kirsten. The Responsibility to Protect and the International Criminal Court: counteracting the crisis. International Affairs. Vol. 91, 2015, pp. 37-54.

ALderSON, Kai; HURRELL, Andrew. Hedley Bull on international society. Great Britain: Palgrave, Macmillan, 1999.

ANNAN, Kofi. Opening Remarks. Humanitarian Action: a Symposium, 20 nov. 2000. International Peace Academy Conference Report. New York: International Peace Academy, 2001.

B00TH, Ken. Human wrongs and IR. International Affairs. Vol. 71, 1995, p. 103-126.

BULL, Hedley. Justice in International Relations: The 1983 Hagey Lectures (1984). In:

In: ALDERSON, Kai; HURRELL, Andrew. Hedley Bull on international society. Great Britain: Palgrave, Macmillan, 1999, p. 206-246.

The anarchical society: a study of order in world politics. New York: Columbia University Press, 2002.

The Grotian conception of international society (1966). In: ALDERSON, Kai; HURRELL, Andrew. Hedley Bull on international society. Great Britain: Palgrave, Macmillan, 1999, p. 95-125.

The Twenty Years `Crisis Thirty Years On. In: ALDERSON, Kai; HURRELL, Andrew. Hedley Bull on international society. Great Britain: Palgrave, Macmillan, 1999, p. 125-139. 
BROWN, Chris. The development of international relations theory in the United Kingdom: traditions, contemporary perspectives and trajectories. International Studies, 46 (1-2), 2009, pp. 221- 237.

BUZAN, Barry. The primary institutions of international society. From international to world society? English School Theory and the social structure of globalization. Cambridge: Cambridge University Press, 2004

CARR, Edward Hallett. Vinte anos de crise: 1919-1939. Uma introdução ao estudo das relações internacionais. Brasília: Editora da Universidade de Brasília, IPRI. 2ª edição, 2001.

DAHL, Robert A. Can international organizations be democratic? A skeptic's view. In: SHAPIRO, Ian; HACKER-CORDÓN, Casiano. Democracy's Edges. Cambridge: CUP, 2001.

DUNNE, Tim. Inventing international society: a history of the English School. London: Macmillan, 1998.

New thinking on international society. British Journal of Politics and International Relations. Vol. 3, n. 2, 2001, p. 223-244.

System, state and society: how does it all hang together? Millennium: Journal of International Studies. Vol. 34, n. 1, 2005, p. 157-170.

The English School. In: ; KURKI, Milja; SMITH, Steve. International relations theories: discipline and diversity. New York: Oxford University Press, 2007, p. 127-148.

; WHEELER, Nicholas. Hedely Bull's pluralism of the intellect and solidarism of the will. International Affairs. Vol. 72, n. 1, 1996.

; GIFKINS, Jess. Libya and the state of intervention. Australian Journal of International Affairs. Vol. 65, n. 5, 2011, pp. 515-529.

ECKERT, Amy E. How the English school can learn to stop worrying and love international ethics. Disponivel em: http://www.isawest.org/EckertlSAWest06.doc, 2006, p. 1-18.

FOCARELLI, Carlo. The Responsibility to Protect Doctrine and Humanitarian Intervention: Too Many Ambiguities for a Working Doctrine. Journal of Conflict \& Security Law. Vol. 13 No. 2, 2008, pp. 191-213.

HAAS, Peter. Epistemic communities and international policy coordination. International Organization. Vol. 46, n. 1, 1992, pp 01-35.

HURRELL, Andrew. Order and justice in International Relations: what is at stake? In:FOOT, Rosemary, GADDIS, John \& HURRELL, Andrew. Order and justice in international relations. United States: Oxford university Press, 2004.

Sociedade internacional e governança global. Lua Nova, n. 46, 1999, p. 55-75.

ICISS. The Responsibility to Protect: report of the International Commission on Intervention and State Sovereignty. Ottawa: International Development Research Centre, 2001.

ICISS. Online. https://www.unitar.org/ny/sites/unitar.org.ny/files/69974_eng_175_Ipi.pdf. Último acesso em 10 de maio de 2015.

ICRToP. The Crisis in Libya. Disponivel em: http://www.responsibilitytoprotect.org/index.php/crises/ crisis-in-libya. Último acesso em 24 de junho de 2015. 
ISA PROGRAM. Toronto 2014 Program and Eventos. Online. Disponivel em: http://www.isanet.org/ Portals/0/Media/Conferences/Toronto2014/Toronto\%202014\%20-\%20Full\%20Program.pdf. Último acesso em 10 de junho de 2015.

JACKSON, Robert. The global covenant: human conduct in a world of states. Oxford: Oxford University Press, 2003.

JONES, Roy. The English School of International Relations: a Case for Closure. Review of International Studies. Vol. 7, n. 1, 1981, pp. 1-13.

KEENE, Edward. International society as an ideal type. In: NAVARI, Cornelia. Theorising International Society: English School Methods. US: Palgrave Mcmillan, 2009.

LINKLATER, Andrew. Cosmopolitan political communities in International Relations. International Relations. Vol. 16, n. 1, 2002, p. 135-150.

Cosmopolitanism. In: DOBSON, A.; ECKERSLEY, R (eds.). Political theory and the ecological challenge. Cambridge: Cambridge University Press, 2006.

The question of the next stage in International Relations Theory. Millennium, Vol. 21, 1992, p. 77-98

The transformation of political community. Cambridge: Polity Press, 1998.

The evolving spheres of international justice. International Affairs. Vol. 75, n. 3, 2003.

;SUGANAMI, Hidemi. The English School of International Relations: a contemporary reassessment. United Kingdom: Cambridge University Press, 2006.

MORRIS, Justin. Libya and Syria: R2P and the spectre of the swinging pendulum. International Affairs. Vol. 89, 2013, pp. 1265-1283.

MARCONI, Cláudia A. Da internacionalização dos direitos humanos aos direitos humanos internacionais: a contribuição da teoria normative para pensar os direitos humanos a partir de RI. Monções: Revista de Relações Internacionais da UFGD, v. 3, 2015, pp. 66-90.

NARDIN, Terry. International political theory and the question of justice. International Affairs. Vol. 82, n. 3, 2006, p. 449-465.

Lei, moralidade e as relações entre os estados. Rio de Janeiro: Editora Forense, 1987.

SCHOUENBERG, Laust. A New Institutionalism? The English School as International Sociological Theory. International Relations. Vol. 25, n. 1, 2011, pp. 26-44.

English School and Institutions: British Institutionalists. In: NAVARI, Cornelia; GRENN, Daniel. Guide to the English School of International Relations. UK: Wiley Blackwell, 2014.

SUGANAMI, Hidemi. British institutionalists, or the English School, 20 years on. International Relations. Vol. 17, n. 3, 2003, p. 253-271.

. On Hedley Bull's The Anarchical Society. Presented to 4th Pan-European International Relations Conference, 8-10 September 2001, University of Kent at Canterbury. Disponivel em http:// www.leeds. ac.uk/polis/englishschool/suganami-bull01.doc. 
The English School and International Theory. In: BELLAMY, Alex (org.). International society and its critics. United States: OUP, 2005, p. 30-44.

VINCENT, J. R. Human rights and international relations. Cambridge: Cambridge University, 1986.

Non-intervention and international order. Princeton: Princeton University Press, 1974.

WAEVER, Ole. Four Meanings of International Society: A Trans-Atlantic Dialogue. In: ROBERSON, B. A. (ed.) International Society and the Development of International Relations Theory, pp. 80-143. London: Pinter, 1998.

WHEELER, Nicholas. Guardian angel or global gangster? The ethical claims of international society. Political Studies. Vol. 44, n. 1, 1996, p. 123-135.

Saving strangers: humanitarian intervention and international society. Oxford: Oxford University Press, 2002.

WIGHT, Martin. A Política do poder. Brasília: IPRI: 2002.

International theory: the three traditions. New York: Holmes \& Meier; London: The Royal Institute of International Affairs, 1991.

Why is there no international theory? In: BUTTERFIELD, Herbert; WIGHT, Martin. Diplomatic investigations. London: Allen \& Unwin, 1966.

WILLIAMS, John. Pluralism, solidarism and the emergence of world society in English School Theory. International Relations. Vol. 19, n. 1, 2005, p. 19-38.

WILLIAMS, Jonh. Pluralism in a solidarist age (or why Hedley Bull does pluralism no favours). Paper for panel 60 - The Nature of International Society. BISA 22th Annual Conference, 2002.

Recebido em: 06 out. 2015

Aceito em: 19 nov. 2015 